İki farklı bonding

sisteminin

erozyonlu mine

dokusunda

bağlanma

dayanımlarının

karşılaştırılması

\section{Comparison of microtensile bond strength of two different bonding systems on eroded enamel}

\section{Yrd. Doç. Dr. Alev Özsoy}

Medipol Üniversitesi, Diș Hekimliği Fakültesi, Restoratif Diş Tedavisi A.D., İstanbul

Yrd. Doç. Dr. Mahmut Kuşdemir

Medipol Üniversitesi, Diş Hekimliği Fakültesi, Restoratif Diş Tedavisi A.D., İstanbul

Geliş tarihi: 7 Şubat 2017

Kabul tarihi: 8 Mart 2017

DOI: 10.5505/yeditepe.2017.40469

\section{Yazışma Adresi:}

Yrd. Doc. Dr. Mahmut Kuşdemir

Medipol Üniversitesi, Diş Hekimliği Fakültesi,

Restoratif Dis Tedavisi A.D.

Unkapanı, Atatürk Bulvarı No:27 34083 İstanbul

Tel: +90 2125212377

E-posta:mkusdemir@gmail.com
ÖZET

Amaç: Dental erozyon geri dönüşümü olamayan, çürüksüz sert doku kaybıdır. Ağız ortamında bulunan iç ya da dış kaynaklı asitler dental erozyonun ana etyolojik faktörüdür. Başta mine dokusu olmak üzere diğer diş sert dokuları da asitlerden etkilenerek çözünmeler gösterebilmektedir. Aynı zamanda bu çözünme sonucu restorasyonun diş dokusuna bağlanması da etkilenmektedir. Bu çalışmada normal ve erozyona uğramış mine dokusuna uygulanan farklı universal bonding sistemlerin mikrogerilme bağlanma dayanımları incelenmiştir.

Gereç ve Yöntem: Portakal suyunda bekletilerek yapay erozyon oluşumu sağlanan mine yüzeyleri ve sağlam mine yüzeylerinde bir Univeral Bonding Sistem birde totaletch olarak uygulanan bonding sistemin mikrogerilme bağlanma dayanımları karşılaştııımıştır.

Bulgular: En yüksek bağlanma dayanım değeri Single Bond Universal kullanılan sağlam mine yüzeyli grupta çıkarken en düşük değerler Single Bond 2'nin kullanıldığı erozyonlu grupta görülmüştür.

Sonuçlar: Elde edilen sonuçlara göre erozyona uğramış dişlerde mikro gerilme bağlanma değerleri istatistiksel olarak anlamlı derecede düşük çıkmıştır

Anahtar kelimeler: Dentin bonding, mikrogerilme bağlanma, dental erozyon.

\section{SUMMARY}

Aim: Dental erosion is loss of hard tissues on tooth surface with an irreversibl, non-carious lesion. Main ethiological factor of this hard tissue loss is extrinsic and intrinsic acids. Not only the enamel but also the other hard tissues of tooth can be dissolved by these acids. This dissolution process is also effect the bonding of restoration materials to the tooth structures. During the treatment procedures, different restoration materials can be used as an alternative approach. In this study, microtensile bond strength of different universal bonding systems on eroded and sound enamel tissue is evaluated. Materials and Method: Orange juice was used to make artificial erosion lesions on two groups. A universal bonding system and a total-etch system were used to evaluate the microtensile bond strength on both eroded and sound enamel. Results: While, the highest microtensile bond values are obtained in Single Bond Universal used on sound enamel group. In the Single Bond 2 used eroded enamel group has shown the lowest bonding values.

Conclusions: According to the results, the microtensile bond strength values of bonding systems on eroded enamel surface is statistically less then sound enamel.

Key words: Dentin bonding, microtensile bond strength, dental erosion. 


\section{GíRiş}

Yaşam boyunca dişler ağız ortamında mikroorganizma bulunmasa da sert dokularında çeşitli aşınma ve/veya kopmaya maruz kalırlar. ${ }^{1}$ Diş dokularında süregelen bu kayıp fizyolojiktir. Ancak meydana gelen doku kaybının oranı dişe zarar verecek boyutlara ulaştığında patolojik olarak nitelendirilir. Çürük olmaksızın dişte sert doku kaybına neden olan süreçler; abrazyon, atrisyon, abfraksiyon ve erozyon olarak sıralanabilir. ${ }^{1-3}$ Dental erozyon lezyonu, ağız ortamındaki serbest asitler tarafından diş sert dokularının çözünmesi sonucunda demineralize olmuş yüzeyel tabakadaki madde kaybı olarak tanımlanır ${ }^{4}$ ve ilk kez Pindborg tarafından 1970' de tanımlanmıştır. ${ }^{1,2}$

Minenin kritik pH değerinin yaklaşık 5.5 olması nedeniyle daha düşük pH değerindeki herhangi bir çözeltinin uzun süreli ve sık uygulanmasının erozyona neden olduğu

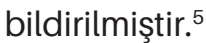

$\mathrm{Bu}$ asitler mide asidi gibi intrinsik veya gıdalardan kaynaklı ekstrinsik asitler olabilir ancak sadece asitlerin fazla tüketimi tek başına erozyondan sorumlu değildir, bireyin ağız bakımı gibi davranışsal özellikleri ya da tükürük tamponlama kapasitesi gibi biyolojik birçok faktör erozyon oluşmasında etkin rol oynar. ${ }^{6}$

Intrinsik asitler; vücuttan kaynaklı asitlerdir ve mide asidinin özofagus ve ağıza geri akması yoluyla dişlerde erozyona neden olurlar. ${ }^{3}$ Sinirsel kusma, anoreksia nevrosa veya blumia gibi yeme bozukluklarının yanında; hamilelik, alkolizm, gastrointestinal bozukluklar da intrinsik erozyona neden olurlar. ${ }^{3,7}$

Ekstrensek asitler; asitli içecekler, yiyecekler, ilaçlar ve çevresel asitler olarak sayılabilir. Ekstrinsik asitler içinde en yaygın olanı diyet asitleridir. ${ }^{3}$

Erozyon yalnızca mine dokusunda madde kaybına neden olabildiği gibi ileri vakalarda dentinin açığa çıkması ile dentin dokusunda da madde kaybına neden olabilmektedir. $^{8}$

Yapılan çalışmalarda farklı çürük dışı progresif sert doku kayıpları içinde en fazla erozyonun görüldüğünü belirtilmiş. ${ }^{9}{ }^{10}$ ve popülasyonlar içinde mine aşınmalarının dentin aşınmalarına göre daha fazla görüldüğü bildirilmiştir. ${ }^{11}$

Bu çalışmada, portakal suyu içinde bekletilerek oluşturulmuş mine erozyonlarında, 2 farklı universal bonding ajanın bağlanma dayanımları mikrogerilme bağlanma dayanım testi kullanılarak değerlendirilmiştir.

\section{GEREÇ ve YÖNTEM}

\section{Dişlerin seçimi ve hazırlanması}

Araştırmamızda kullanılmak üzere sağlıklı ve yaşları 20-35 arasında olan bireylerden çekilmiş apeksifikasyonu tamamlanmış tam gömük 3. molar dişler kullanılmıştır. Dişlerin seçiminde çatlak ve çekim travması olmamasına dikkat edilmiştir. Diş sayısı 40 olarak belirlenmiştir.

Dişlerin üzerindeki yumuşak doku artıkları kemik parçacıkları periodontal bir küret yardımı ile uzaklaştırıldıktan sonra pomza kullanılarak temizlenmiş ve oda sıcaklığındaki distile su içerisinde en fazla 3 ay bekletilmiştir. Dişlerin içinde bulunduğu solüsyonlar deneyler başlayana kadar her hafta değiştirilmiştir.

\section{Dişlerin gruplandırılması ve düz mine yüzeylerinin elde edilmesi}

Dişler her grupta 5 diş olacak şekilde rastgele 4 gruba ayrılmıştır. Çalışmada kullanılan adeziv sistemler ve içerikleri, Tablo 1'de gösterilmiştir. Doku artıklarından temizlenen dişler 2 kat tırnak cilası ile boyandıktan sonra ekvator hatıının altında kalan kuronal 1/3 bölümlerinden $3 \times 4 \mathrm{~mm}^{2}$ lik alan, periodontal sond ile ölçüm yapılarak sabit kalem ile işaretlenmiştir. İşaretlenen alanlarda karbon disk yardımıyla $3 \times 4 \mathrm{~mm}^{2}{ }^{\prime}$ lik düz mine yüzeyleri elde edilmiştir.

\begin{tabular}{|c|c|c|}
\hline Materyal & Üretici Firma & Kimyasal İçerik \\
\hline Single Bond 2 & $\begin{array}{l}\text { 3M ESPE } \\
\text { Germany }\end{array}$ & $\begin{array}{l}\text { Etil alkol, Bisfenol A diglisidil } \\
\text { metakrilat (bis-GMA) } \\
\text { 2-Hidroksietilmetakrilat } \\
\text { Akrilik ve itakonik asit } \\
\text { kopolimeri } \\
\text { Diüretandimetakrilat, su }\end{array}$ \\
\hline $\begin{array}{l}\text { Single Bond } \\
\text { Universal }\end{array}$ & $\begin{array}{c}\text { 3M ESPE AG } \\
\text { Germany }\end{array}$ & $\begin{array}{c}\text { 10-MDP, bis-GMA, HEMA, } \\
\text { hidrofilik alifatik metakrilat, } \\
\text { kolloidal silika,kamfarokinon, } \\
\text { akseleratör,initiatör,etanol,su }\end{array}$ \\
\hline $\begin{array}{l}\text { 3M Filtek } \\
\text { Ultimate }\end{array}$ & $\begin{array}{l}\text { 3M ESPE, St. Paul, } \\
\text { MN, USA }\end{array}$ & $\begin{array}{l}\text { Bis_GMA, UDMA, Bis-EMA, } \\
\text { TEGMA, PEGDMA,silika } \\
\text { doldurucu,zirkonya doldurucu }\end{array}$ \\
\hline
\end{tabular}

\section{Erozyona uğratılmış yüzeylerin hazırlanması}

Mine yüzeylerinde hazırlanan $3 \times 4 \mathrm{~mm}^{2}$ lik alanların erozyona uğratılması için, dişler 24 gün boyunca, günde 6 defa 5 'er dakika portakal suyunda bekletilip, daha sonra distile su ile yıkanmış, kalan sürelerde de, oluşturduğumuz yapay tükürükte bekletilmiştir. Yani dişler, 24 gün boyunca günde 30 dakika olmak üzere, toplam 12 saat portakal suyu ile temas etmiştir.

\section{Bağlanma Dayanım Değerlendirilmesi İçin Örneklerin Hazırlanması}

Karbon disklerle elde edilen normal ve erozyona uğratılmış düz mine yüzeylerine üretici firmanın talimatları doğrultusunda 30 saniye süreyle asit uygulandıktan sonra basınçlı su ile yıkanmış ve havayla kurutulmuştur. Daha sonra yüzeylere Single Bond 2 ve Single Bond Universal (3M Espe) uygulandıktan sonra hafif basınçlı hava sıkılarak bağlayıcı ajanın yüzeye yayııması sağlanmıştır. 10 saniye süreyle LED ışık cihazı (Faro, Monza Brianza, Italya) ile polimerizasyon gerçekleştirilmiştir. Hazırlanan şekillendirilmiş matrix bandı yardımıyla, yüzeylere, $2 \mathrm{~mm}$ kalınlığında kompozit (3M Filtek Ultimate) uygulanarak restorasyon tamamlanmıştır. Çalışmada kullanılan adeziv 
sistemler ve içerikleri Tablo 1'de gösterilmektedir. Dişler, su soğutması altında düşük devirde dönen bir elmas keski (Isomet 1000, Buehler, Lake Bluff, IL, ABD) ile bağlanma yüzeyine dik olarak prepare edildi. Her bir mine yüzeyinden, yaklaşık 8-9 mm uzunluğunda kare kesitli çubuk şeklinde örnekler elde edildi.

\section{Mikrogerilme Bağlanma Dayanım Testi}

Örnekler, test araçlarına her iki ucundan siyanoakrilat bir yapıştırıcı (Model Repair II Blue, Dentsply-Sankin, Ohtawara, Japonya) ile sabitlendi ve bu sırada yapıştıııının bağlanma yüzeyine bulaşmamasına dikkat edildi. Örnekler kopma elde edilinceye kadar universal test cihazında (Lloyd, Hampshire, İngiltere) $1 \mathrm{~mm} / \mathrm{dk}^{\prime}$ lık hızda gerilme kuvveti uygulanarak strese maruz bırakıldı. Kopma anındaki kuvvetin (N) bağlanma yüzey alanına $\left(\mathrm{mm}^{2}\right)$ bölünmesiyle elde edilen mikrogerilme bağlanma dayanımı değeri megapaskal $\left(\mathrm{MPa}, \mathrm{N} / \mathrm{mm}^{2}\right)$ cinsinden ifade edildi. Her materyal için ortalama bağlanma dayanım değeri 20 çubuğa ait mikrogerilme değerleri kullanılarak elde edildi.

\section{İstatistiksel analiz}

Elde edilen veriler SPSS 16.0 paket programı kullanılarak istatistiksel olarak değerlendirildi. Dağılımın belirlenmesi amacıyla Kolmogrov-Smirnow testi, grupların karşılaştırmasında Kruskal-Wallis testi kullanıldı. Gruplar arasındaki farkları belirlemek için Post Ad Hoc Tukey testi kullanıldı ve anlamlılık değeri 0,05 olarak kabul edildi.

\section{BULGULAR}

Tüm gruplara ait MPa cinsinden bağlanma dayanım değerleri Tablo 2'de verilmiştir Mikrotensile testi sonrası elde edilen verilere göre, Single Bond Universal grubunun diğer gruplarla karşılaştırıldığında istatistiksel olarak en yüksek bağlanma dayanımı değerine sahip olduğu gözlenmiştir $(p<0,05)$. En yüksek bağlanım değerleri Single Bond Universal grubunda $(42,79 \pm 2,85)$ gözlemlenirken, en düşük değerlere sahip olan grubun erozyona uğratılmış Single Bond 2 olduğu belirtilmiştir $(25,9 \pm 1,71)$. Analiz sonuçlarına göre erozyonun mikro-gerilme bağlantı değerleri üzerinde etkili olduğu görülmüştür $(p<0,05)$. Bütün gruplar arasında istatistiksel olarak anlamlı fark bulunmuştur $(p<0,05)$.

\section{TARTIŞMA}

Dental erozyonların tedavisinde; madde kaybı nedeniyle bozulmuş olan servikal bölge fizyo-morfolojisini yeniden oluşturmak, diş eti sağlığını korumak, ön bölgede estetiği sağlamak amacıyla adeziv sistemlerin kullanıldığı minimal invaziv restorasyonlar uygulanabilmektedir. ${ }^{1}$

Minimal invaziv hatta non-invaziv tedavi uygulamaları gün geçtikçe restoratif diş tedavisi içinde önem kazanmaktave endikasyon alanını genişletmektedir. Bu nedenle erozyon lezyonlarının tedavisinde de non-invaziv yöntemin uygulanması, lezyon nedeniyle madde kaybına uğramış dişin bir de kavite preparasyonu ile daha fazla madde kaybına uğramasını önlemek amacıyla yapılmaktadır. Bu araştırma, mine dokularındaki yapay erozyon yüzeylerine uygulanan kompozit restorasyonun mikro-gerilme bağlanma dayanım gücünü ölçmek amaçlanmıştır.

Tablo 2: Gruplara ait (ortalama, standart sapma, minimum, maksimum) değerler.

\begin{tabular}{|c|c|c|c|c|c|}
\hline & $\mathrm{N}$ & $\begin{array}{c}\text { Ortalama } \\
\text { değer }\end{array}$ & $\begin{array}{c}\text { Standart } \\
\text { Sapma }\end{array}$ & Min. & Maks. \\
\hline Single Bond 2 & 10 & 38,37 & 2,46 & 33,90 & 41,10 \\
\hline $\begin{array}{c}\text { Single Bond } \\
\text { Universal }\end{array}$ & 10 & 42,79 & 2,85 & 39,40 & 46,90 \\
\hline $\begin{array}{c}\text { Erozyonlu } \\
\text { Single Bond 2 }\end{array}$ & 10 & 25,9 & 1,71 & 23,10 & 28,40 \\
\hline $\begin{array}{c}\text { Erozyonlu } \\
\text { Single Bond } \\
\text { Universal }\end{array}$ & 10 & 30,1 & 2,67 & 26,80 & 33,60 \\
\hline
\end{tabular}

Reçine esaslı kompozit materyallerin uygulandığı bağlanma dayanımlarının değerlendirilmesinde kullanılan çekme ve makaslama kuvvetlerinin dayanımını ölçen test yöntemlerinden, en çok tercih edilenleri makro ve mikro-gerilme bağlanma dayanımı testleridir. ${ }^{12}$

Günümüzde sağlıklı beslenme adı altında günlük alınan öğün sayısının artması ve yine sağlıklı beslenmeye önem verildiği için portakal suyunun diğer asitli içeceklere göre daha sık tüketilmesi nedeniyle ağız ortamının maruz kaldığı asit atakları taklit edebilmek amacıyla dişler 24 gün boyunca, günde 6 defa 5'er dakika portakal suyunda bekletilip, daha sonra distile su ile yıkanmış, kalan sürelerde yapay tükürükte bekletilmiştir. ${ }^{13-15}$

In vitro çalışmaların bir dezavantajı ağız ortamının birebir taklit edilememesidir. Dişler erozyona uğratıırken ağız ortamına en yakın şartları hazırlayabilmek ve erozyon sürecinde var olan demineralizasyon ve remineralizasyonu taklit edebilmek amacıyla yapay tükürük kullanılmıştır. Total-etch tekniği uygulanarak 30'ar saniye süreyle mineyi asitleme işlemi gerçekleştirilmiş ardından iki bonding ajan erozyona uğratıımış ve uğratılmamış mine dokusuna uygulanmıştır. Araştırmadaki hedef erozyona uğratılmış diş sert dokularında rutin kullanılan yöntemlerle yapılan adeziv işlemlerin başarısını sağlıklı dokulardaki ile karşılaştırarak incelemektir.

Asit süreleri sabit tutularak erozyona uğratılmış dokuya bağlanma değerleri ile sağlıklı dokuya bağlanma değerleri arasında anlamlı farkların görülmesi erozyona uğratılmış dokunun değişikliğe uğradığının kesin kanıtı olmuştur.

Erozyon sırasında demineralizasyon ve remineralizasyon süreçleri nedeniyle erozyona uğrayan yüzeyde Ca tuz çökelmeleri olacağını varsayarak bu çökelmeleri ortadan kaldırmak için total-etch tekniği uygulaması tercih 
edilmiştir. Erozyona uğratılmamış gruplara bakıldığında Single Bond Universal grubunun bağlanım değerinin $(42,79 \pm 2,85)$ Single Bond $2(38,37 \pm 2,46)$ grubundan büyük olduğu görülmüştür. Erozyona uğratılmış grupta da Single Bond Universal grubunun bağlanım değeri $(30,1 \pm 2,67)$ Single Bond $2(25,9 \pm 1,71)$ grubundan büyüktür.

Erozyona uğramış mine eroziv madde (portakal suyu) sebebiyle daha uzun süre asite maruz kalmıştır. Erozyona uğramış mine üzerinde gerçekleşen bağlanım değerlerinin daha düşük olduğu, fakat Universal Bonding uygulamasının bağlanım değerlerini arttırmış olduğu tespit edilmiştir.

Bağlanma dayanımlarındaki farklılık materyalin kimyasal özelliklerinden etkilenmektedir çünkü normal sağlıklı minede her iki bonding sisteminin bağlanma dayanım değerleri yüksektir. Bu sebeple erozyona uğramış yüzeyin tutunmayı etkilediği kanısındayız. İçecekler sonucunda meydana gelen erozyonda diş minesindeki kayıp, devamlı Ca eksilmesi, çözeltiye eklenen fosfor, oksijen ve hidrojen iyonları ile ilişkilendirilebilir. Dental doku demineralize olduğunda daha da zayıflar ve güçsüzleşir. ${ }^{16,17}$

\section{SONUÇ}

Yapılan istatistiksel analizler sonucunda, erozyona uğramış mine yüzeylerinde bağlanma değerleri sağlam mine yüzeylerindeki değerlere göre daha düşük çıkmıştır. Klinikte, bu tip erozyona uğramış dişlerin restorasyonları öncesinde gerek materyal seçimi aşamasında gerekse işlem esnasında azami dikkat gösterilmelidir. Uygun bağlayıcı ajan ve kompozit rezin seçimiyle daha uzun ömürlü restorasyonlar yapılması olasıdır.

\section{KAYNAKLAR}

1.Lussi A (ed): Dental Erosion. Monogr Oral Sci.Basel, Karger, 2006; 20: 1-8

2.Atilla E, Eden E. Dental Erozyon: Etiyoloji, tanı ve tedavi yaklaşımı. EÜ Dişhek Fak Derg 2011; 33: 56-63

3.Gandara BK, Truelove EL. Diagnosis and management of dental erosion. The Journal of Contemporary Dental Practice 1999; 1: 1-17

4.Wiegand A, Kuhn M, Sener B, Roos M, Attin T. Abrasion of eroded dentin caused by toothpaste slurries of different abrasivity and toothbrushes of different filament diameter Journal of Dentistry 2009; 37: 480-484.

5.Jaeggi T, Lussi A: Toothbrush Abrasion of Erosively Altered Enamel after Intraoral Exposure to saliva: An in situ study. Caries Res 1999; 33: 455-461.

6.Lussi A, Jaeggi T, Zero D. The role of Diet in the Aetiology of Dental Erosion. Caries Res 2004; 38: 34-44.

7.Moss SJ. Dental Erosion. Int Dental Journal 1998; 48 : 529-535.

8.Wilder AD, Swift EJ,Jr, Heymann HO, et al.: A 12-year clinical evaluation of a three-step dentin adhesive in noncarious cervical lesions. J Am Dent Assoc 2000; 140: 526535.

9.Lussi A, Schaffner M. Progression of and risk factors for dental erosion and wedge-shaped defects over a 6- year period. Caries Res. 2000; 34: 182-187.

10.Nunn JH, Rugg-Gunn A, Gordon PH, Stephenson G. A longitudinal study of dental erosion in adolescent girls. Caries Res. 2001; 35: 296 (ORCA abstr. 97).

11.Dugmore CR, Rock WP: The prevelance of tooth erosion in a cohort of adolescents of mixed ethnicity. Int $\mathrm{J}$ Paediatr Dent 2003; 13: 295-303.

12.Van Meerbeek B, De Munck J, Yoshida $Y$, Inoue $S$, Vargas $M$, Vijay $P$, Van Landuyt $K$, Lambrechts $P$, Vanherle G. Adhesion to Enamel and Dentin: Current Status and Future Challenges. Operative Dentistry, 2003;28: 215235.

13. Barbour ME, Rees GD. The role of erosion, abrasion and attrision on tooth wear. J Clin Dent 2006; 17: 88-93.

14. Ren $Y F$, Zhao $Q$, Malmstrom $H$, Barnes $V$, Xu T. Assessing fluoride treatment and resistance of dental enamel to soft drink erosion in vitro: Applications of focus variation 3D scanning microscopy and stylus profilometry, J Dent, 2009; 37: 167-176.

15.Scaramucci T, Hara AT, Zero DT, Ferreira SS, Aoki IV, Sobral MA. In vitro evaluation of the erosive potentail of orange juice modified by food additives in enamel and dentine. J Dent, 2011; 39:841-848.

16.Barbour ME, Finke M., Parker DM, Hughes JA, Allen GC, Addy M. The relationship between enamel softening and erosion caused by soft drinks at a range of temperatures. J Dent. 2006: 34: 207-213.

17.Van Eygen I, Vannet BV, Wehrbein H. Influence of a soft drink with low $\mathrm{pH}$ on enamel surfaces. Am. J Orthod Dentofac Orthoped 2005: 128; 372-379. 